\title{
Seismicity around Sri Lanka from Historical Records and its Engineering Implications
}

\author{
H.N. Seneviratne, L.R.K. Perera, K.K. Wijesundara, R.M.S. Dananjaya and \\ U. de S. Jayawardena
}

\begin{abstract}
This paper describes a study carried out to analyse the historical records of earthquakes in the vicinity of Sri Lanka. The records indicate that the 1615 earthquake was the most significant earthquake that affected Sri Lanka. By analysing over 300 records of earthquakes around Sri Lanka, it was found that Mannar rift zone and Comorin ridge is the critical zone of influence which is capable of generating a seismic event of magnitude 6.9 at a 475 year return period at a depth of $10-$ $15 \mathrm{~km}$ below the sea level. The study demonstrates that seismicity around Sri Lanka cannot be no longer ignored and engineering design should include seismic hazards.
\end{abstract}

Keywords: $\quad$ Past Earthquakes, Failed Mannar Rift Zone, Gutenberg - Richter Relationship

\section{Introduction}

Sri Lanka is located in the North Western region of the Indo-Australian plate. The interplate seismic activity around this plate is governed by Himalayas to the north on which it pushes against the Euroasian plate and by Sunda trench to the east on which it undergoes subduction causing earthquakes and tsunamis. The seismic activity to the far west at the midIndian ocean ridge, and to the south is less significant in comparison to the above, as the former are zones of crustal extension compared to zones of compression in the north and east. However, some seismologists discuss the possibility of emergence of a new plate boundary to the south of Sri Lanka [4]. The above interplate events are not considered significant as far as Sri Lanka is concerned [20] but the tsunami hazard due to seismic activity at the Sunda trench is considerable.

In the present study, the intraplate activities spanning northwest to southwest coasts of Sri Lanka in the vicinity of failed Mannar rift zone and the Comorin ridge which were not hitherto considered important are analysed in detail. This is particularly important considering the heavily populated and economically important areas near the west coast and/or within the western province. The intraplate activities originating in the other regions around Sri Lanka are not considered important except to the north where intraplate seismic activity in South India may have some influence on the northern region of Sri Lanka. The intraplate seismic activity within Sri Lanka appears to be not significant [7].

\section{Geological Significance of Failed Mannar Rift Zone and Comorin Ridge}

Sri Lanka is believed to be geologically the southern continuation of peninsular India although the island today is separated from the mainland India by a narrow stretch of shallow sea. This stretch of sea is now a part of the Indian Ocean, but it opened-up as Sri Lanka drifted way from India at the time the super continent Gondwana break-up during the Jurassic period [3], [2], [12]. Continued rifting of continents always leads to formation of large ocean basins but it produces narrow seas or inland lakes at initial stages.

Rifting produces faulted blocks of rocks, with the faulting extending laterally for tens to hundreds of kilometers and vertically downward to the mantle, providing pathways for rising magma. Zones of initial rifting therefore, are always geologically very active as they are sites of active volcanism and seismicity.

Eng. (Prof.) H.N. Seneviratne, FIE(SL), BScEng (Ceylon), PhD (Cambridge), Senior Professor, Department of Civil Engineering, University of Peradeniya.

Email:nimalseneviratne1@gmail.com

(iD http://orcid.org/0000-0001-5352-2652

Mr. L.R.K. Perera, BSc (Peradeniya), MPhil (Peradeniya), Senior Lecturer, Department of Geology, University of

Peradeniya.

Eng. (Dr.) K.K. Wijesundara, AMIE(SL), BScEng (Peradeniya), MScEng (Pavia), PhD (Pavia), Senior

Lecturer, Department of Civil Engineering, University of

Peradeniya.Email:kushanw@pdn.ac.lk

(iD http://orcid.org/0000-0002-4174-8707

Eng. R.M.S. Dananjaya, AMIE(SL), BScEng

(Peradeniya), MPhil (Peradeniya), Research Assistant,

Department of Civil Engineering, University of Peradeniya.

Email:shyanakad@gmail.com

(D) http://orcid.org/0000-0002-1963-4463

Eng. (Prof.) U. de S. Jayawardena, C. Eng., FIE (SL),

BSc (Peradeniya), MSc (AIT), DEng (Kyushu), Professor,

Department of Civil Engineering, University of Peradeniya

Email:udsj@pdn.ac.lk

(D) http://orcid.org/0000-0001-5952-0439 
Cauvery and Mannar basins produced by the rifting process are floored by faulted blocks of continent and sedimentary successions which are about 10 kilometers thick laid down on the faulted sea floor since the Cretaceous period. During exploratory drilling for oil in the Cauvery and Mannar basins, frozen basaltic lava flows have been encountered [15]. These are inter-layered with sediments indicating that the rift zone had been volcanically and seismically active in the past.

Seismic exploration of the sedimentary succession in the Cauvery and Mannar basins has indicated relative disposition of faulted blocks of rocks on the basin floor. As the sediment load increases one cannot rule out reactivation of the fault zones and relative motion between the already faulted blocks of rocks generating some seismicity. In the Bay of Bengal to the east and northeast of Sri Lanka, there is also evidence of sea floor spreading. The settling of sedimentary successions has given rise to earthquakes with magnitude around 5 in the recent past, the latest being in April 2009. Although highly active seismic zones are quite far away from Sri Lanka, the potential of the above sedimentary basins to the NW and NE of Sri Lanka becoming foci of future moderate magnitude earthquakes (up to M6) has to be borne in mind. However, the seismic status of Sri Lanka is dominated by failed Mannar rift zone and Comorin ridge (NW basin) as very few significant seismic activities have been recorded in the NE basin.

\section{Early Historical Earthquake Records}

The earliest documentary record of an earthquake affecting Sri Lanka is based on a pamphlet published in Lisbon in 1616 describing an event which took place on 14 April 1615 near Colombo [9] [17]. This article is an eyewitness account of the 1615 earthquake printed by Jorge Rodriguez in 1616 in Lisbon brought to light by Fr. S.G. Pereira, an academic in Missionology Georgian University, Rome. The relevant texts extracted from this article are given below in quotation mark.

In the period of several months preceding the main event, the following activities had taken place:

"There were thrown up from the sea a number of dead fish so poisonous that all who ate them died. The putrefaction and bad odour so infected the air that not men but even the birds of the air fell dead". Explanation: This may be due to the slow release of poisonous gas through the opening of fractures in the sea floor. The source of poisonous gas may be the volcanic intrusions themselves or the underground sediments trapped overlying the faulted continent blocks.

The main shock: "On that day the sun set half an hour earlier than on other days. It was seven in the evening when thunder shook the air with such force and the earth quaked so violently that, unable to remain in the houses people rushed out to the streets fearing to be buried under the falling ruins of the buildings. Then bolts of thunder fell from the heavens. The thunderbolts had their effect, destroying and laying low not only the most sumptuous edifices but also the meanest cottages leveling all, and the few that the fire had not consumed were destroyed by the earthquakes".

Explanation: This is consistent with released gas on the western horizon blocking the sun, followed by ground shaking due to the earthquake (initial destruction of property) and subsequent lightning and thunder causing further destruction. The thunder may be due to the energy release of the earthquake and/or else due to gas explosion. The lightning during earthquakes has been observed in a number of earthquake events as described in the next section in literature.

Damages and the aftermath of the earthquake: "There were seen in many parts of the Island vast openings and fissures in the earth, some of which so deep that no one could find the bottom, nor were they closed up for a long time, from which there issued at certain times flames of fire as of Sulphur.

The damage, which this earthquake did was moreover general throughout the Island not only to fruits, trees and crops but also to cattle and other things necessary for human life.

Great grief was caused by the destruction of a large stone bridge, built at great cost and very necessary as it was the most important passage in that Island, the stones of which were afterwards found many leagues away. They made up for it with boats and are already considering the re-erection of the bridge because of their need of it. There fell a good bit of the western wall as well as the whole of the bastion, which was so strong that they thought that nothing could destroy it".

Explanation: The cracks on the earth confirms the event as an earthquake and smell of sulphur from the cracks is due to the escape of gases released through the cracks or as a result of the burning of organic soils in the area.

Based on the damage reported in this article the earthquake is estimated to have a maximum moment magnitude of 6.5 corresponding to an intensity of eight on Modified Mercalli Scale 
[22]. The epicenter of this earthquake cannot be identified due to lack of data. However, it must have originated most likely in the western sea with close proximity to Colombo. The evidence of deep cracks on the ground, gas release and the extent of the damage caused by the earthquake are indicative of severity/proximity of the event which is by far the worst seismic event that had affected Sri Lanka as described in the literature.

\section{Historical Earthquake Records after 1800}

There are no historical records known to the authors for the period from 1615 to 1800. Even though there were no measuring instruments available at that time, earthquakes were reported in proximity to Sri Lanka in Northern Indian Ocean (1823) and Coimbatore-Nilgiri Hills (1900). Interestingly, flash of lightening at the end of earthquake shock is also observed by eyewitnesses in the 1900 earthquake. The phenomena such as appearance of lightening and luminous clouds before/or at the time of earthquakes have been observed in many earthquakes though the scientific reason for this not clearly established [5].

Newspaper reports are available in the National Archives, Sri Lanka on earthquakes that had occurred in or around Sri Lanka in 1882, 1924, 1938 and 1944 (The Ceylon Observer: 1938, 1944). No deaths had been reported in any of the above events though damages to property have been described in some cases. The most significant event appeared to be the 1938 earthquake, the epicenter of which was located along the central axis of the Mannar failed rift zone.

According to the newspaper record of national archives 1938, the event was felt almost throughout the island though there were no casualties or significant damage to property. The tremors were notably felt in the southwest area of the island including the up-country.

The authors are unaware of any records of earthquakes of high intensity affecting Sri Lanka prior to 1615. However, paleoseismologists have investigated such intraplate historical earthquakes that affected Indian subcontinent dating back to 1063 A.D. [16] [8] [13].

\section{Seismographic Records 1909-1992}

A Milne seismograph was installed in Colombo Observatory in 1909. The observations from this seismograph had been connected to a global network comprising 350 seismographic stations. This was replaced by a Milne-Shaw seismograph in 1927 at the location $6^{\circ} 54^{\prime} \mathrm{N}, 79^{\circ}$ $52^{\prime}$ E installed in a layer of sandstone at a depth of $4.2 \mathrm{~m}$ below the ground surface. The records from the above seismograph were published in some of the Annual Reports of Colombo Observatory and in International Seismological Summary, University Observatory, Oxford, England [11]. In addition, the original records are kept at the Department of Meteorology which succeeded the Colombo observatory in 1972. Therefore, measured earthquake data at Colombo should be available from 1909-1992.

The most significant earthquake to affect Sri Lanka during this period occurred in 1938 and the tremors due to it were felt throughout the island though there were no fatal casualties. The seismograph at Colombo observatory was thrown out of action by the earthquake.

Unfortunately however, no data from seismograph at Colombo observatory are available since 1992 as the seismograph was not in a fully functional condition.

\section{Seismometer Records after 1992}

Three seismometers were installed by Geological Survey and Mines Bureau (GSMB), one in 2000 at Pallekele (PALK) connected to Global Seismographic Network (GSN) and the others in 2010 at Mahakandarawa (MALK) and Hakmana (HALK) connected to GEOFON Network. The waveform data and earthquake parameters from these seismometers are available through the internet from the GSN and GEOFON networks through GSMB.

It is imperative that, given the importance of Colombo and suburbs in the Western Province (with the planned Megapolis development) and highly populated North Western province, a network of seismometers be established throughout the island considering the proximity to the west coast. This will enable to find and calibrate appropriate attenuation relationships throughout the island due to impending earthquakes. The detailed data from these seismometers should be readily available to all researchers and relevant professionals. 


\section{Earthquake Catalogue for Intraplate Seismicity in and around Sri Lanka}

Early earthquake catalogues on the seismicity around Sri Lanka were prepared by Vitanage (1995) [22] and Abayakoon (1995) [1]. In addition, a number of Indian catalogues cover many earthquakes in the south Indian region (Menon et.al., 2010). In the present study to investigate the seismicity around Sri Lanka, an area bounded by Latitude $0^{\circ} \mathrm{N}-20^{\circ} \mathrm{N}$ and Longitude $70^{\circ} \mathrm{E}-90^{\circ} \mathrm{E}$ was selected as seen from Figure 1. The records from Abayakoon (1995) [1] and Uduweriya (2014) [21] are based on the data reported by many global data bases such as IRIS data base. The data which goes back to 1063 A.D., consisting of past seismographic observations and estimations based on damage intensity or from paleo seismological studies, was used in preparation of the catalogue.

The epicenters of the earthquakes taken from catalogue are illustrated in Figure 1.

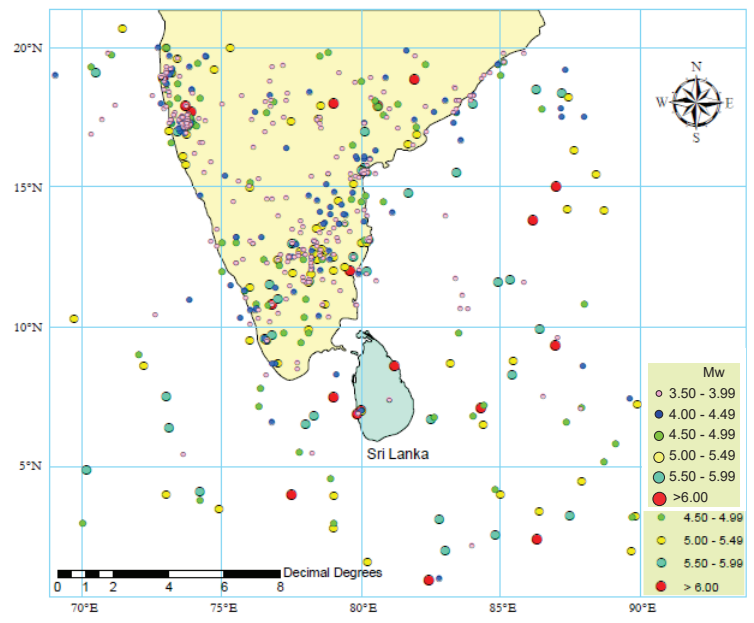

Figure 1 - Epicenters from past earthquakes

It is seen from Figure 1 that a high intensity earthquake zone is concentrated along the NE, SW Indian fault zone going from Ongole to Kerala. However, this fault region is far away from Sri Lanka to have any significant impact on the seismic status of Sri Lanka except in the northern region.

The seismic status close to Sri Lanka appears to be governed by the activities in the western coastal region in which failed Mannar rift zone and Comorin ridge can be identified as the main tectonic features. This is clearly visible in Figure 2, which shows the filtered version of the earthquake catalogue created by narrowing down the original area to $3.5^{\circ} \mathrm{N}-8.5^{\circ} \mathrm{N}$ and $75^{\circ} \mathrm{E}-$ $80^{\circ} \mathrm{E}$ window. Mannar rift zone is named as Mannar lineament in this figure. The seismic activities in the other coastal regions appear to be insignificant in comparison according to the available data at present.

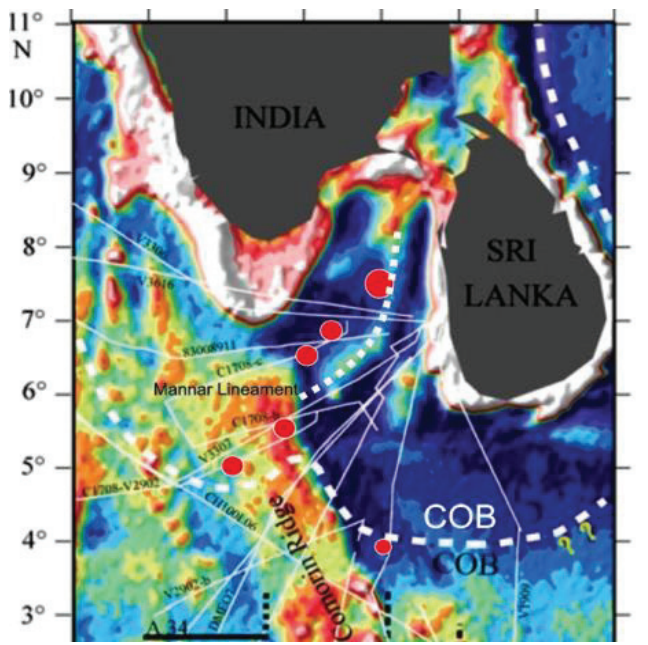

Figure 2 - Epicentres of the earthquake occurred on the Comorin ridge and the surrounding area (Structure and isostatic compensation of the Comorin Ridge, north central Indian Ocean by Sreejith et al., 2008) [18]

\section{Completeness of Earthquake Catalogue}

In order to verify the completeness of the catalogue, the method proposed by Stepp (1973) [19] was adopted [21]. In this method, $\sigma_{\lambda}$ for selected magnitude intervals was plotted against $T$, where $\sigma_{\lambda}$ is the variance of the distribution of earthquake with time, and $\mathrm{T}$ is the time period. This was carried out for a number of magnitude intervals and the results are shown in Figure 3.

The fact that graphs of different magnitude intervals are parallel to each other and each graph is represented by a sufficient number of data points confirm that the catalogue is complete for the time period $1900-2012$.

Since all the earthquake records after 1900 are based on actual seismographic records, the uncertainties originated from estimations based on intensity are eliminated.

With the completeness of the catalogue established, any subset of the catalogue will have the same completeness and can be reliably used in place of the original catalogue. 


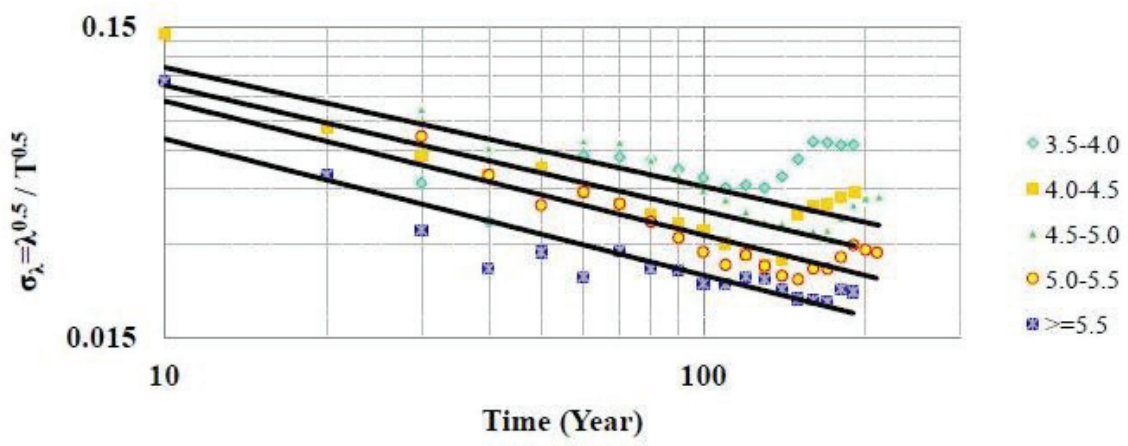

Figure 3 - Completeness time plots in terms of moment magnitude following Stepp [1973] method (Each symbol refers to a different magnitude range)

\section{Return period - Magnitude Relationship of Earthquakes Originated in Comorin Ridge - Failed Mannar Rift Zone}

The return period $(\mathrm{N})$ - magnitude $\left(\mathrm{M}_{\mathrm{w}}\right)$ relationship was established using the procedure described by Gutenberg and Richter (1954) and is shown in Figure 4. The linearity of the relationship with an $\mathrm{r}^{2}$ value of 0.96 demonstrates the high correlation of the data with Gutenberg - Richter relationship.

The earthquake data from the catalogue used to establish the above relationship is given in Table 1. As specified in Eurocode 8 (2005) [6], earthquake magnitudes for 475 year and 2500 year return periods were estimated to be 6.9 and 8.4.

However, from seismological point of view, the magnitude of a shallow crustal earthquake greater than 7.0 is unlikely in seismic scenarios similar to that in Mannar rift zone. Therefore, 2500 year return period earthquake is assumed to have a cut-off magnitude of 7.0.

Given the fact that such earthquakes originate in the fault zone, the focus of the earthquake will be at a depth of $10-15 \mathrm{~km}$ below the sea level. In the recent seismic records obtained from Geological Survey and Mines Bureau (GSMB) of Sri Lanka, this fact has been confirmed.

\section{Engineering Implications}

The present study indicates that seismic risk associated with earthquakes originating within failed Mannar rift zone can have significant impact on the seismic status of Sri Lanka. This seismic risk should be estimated in order to quantify the engineering implications associated. The damage caused by 1615 earthquake is alarming enough to contemplate the potential impact of such an event on capital Colombo and the suburbs.

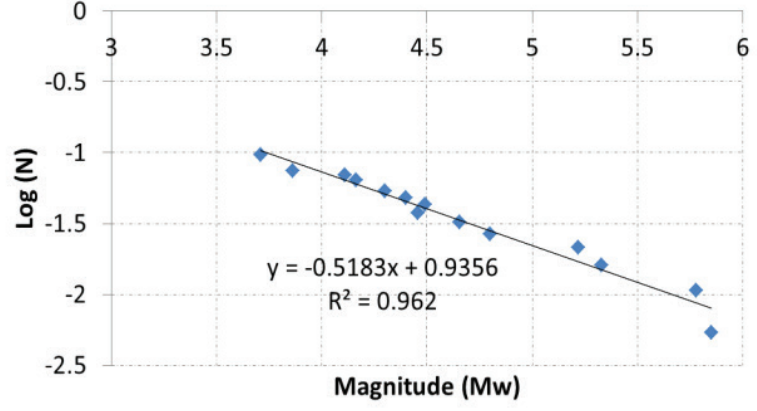

Figure 4 - Gutenberg-Richter Relationship

Table 1 - The earthquake data set

\begin{tabular}{|c|c|c|c|c|}
\hline No & Year & $\begin{array}{c}\text { Lat. } \\
\mathbf{N}\end{array}$ & $\begin{array}{c}\text { Long. } \\
\mathbf{E}\end{array}$ & Magnitude \\
\hline 23 & 1823 & 7 & 80 & 5.8 \\
\hline 26 & 1823 & 7 & 80 & 4.3 \\
\hline 36 & 1843 & 6.9 & 79.9 & 3.7 \\
\hline 37 & 1848 & 6.92 & 79.87 & 4.2 \\
\hline 46 & 1857 & 7 & 80 & 4.8 \\
\hline 70 & 1866 & 7 & 80 & 4.2 \\
\hline 76 & 1871 & 6.92 & 79.87 & 3.7 \\
\hline 106 & 1900 & 6.92 & 79.87 & 3.7 \\
\hline 143 & 1938 & 7.5 & 79 & 5.9 \\
\hline 177 & 1956 & 6.5 & 78 & 5.3 \\
\hline 262 & 1968 & 8.29 & 76.57 & 3.7 \\
\hline 480 & 1986 & 4.6 & 78.9 & 4.7 \\
\hline 502 & 1988 & 7.8 & 76.38 & 4.4 \\
\hline 542 & 1993 & 6.82 & 78.3 & 5.2 \\
\hline 574 & 1998 & 5.49 & 78.24 & 3.9 \\
\hline 578 & 1998 & 5.51 & 77.78 & 4.6 \\
\hline 607 & 2001 & 7.15 & 76.32 & 4.5 \\
\hline 670 & 2010 & 6.6 & 76.78 & 4.1 \\
\hline
\end{tabular}

\section{Conclusions}

A study has been conducted to estimate the seismicity around Sri Lanka based on the historical records. It is concluded that seismic threat to Sri Lanka is mainly due to activities within Mannar rift zone. It has been demonstrated that earthquake catalogue containing the events after 1900 is complete. 
According to the Gutenberg - Richter relationship, an earthquake of magnitude 6.9 (475 year return period) is possible within this region. However, with the present data, it is difficult to pinpoint the exact location of such an event though it may occur at the $10-15 \mathrm{~km}$ depth in the western ocean.

\section{References}

1. Abayakoon, S. B. S. (1996). "Seismic Risk Analysis of Sri Lanka", Journal of Geological Society of Sri Lanka, 6, 65-72.

2. Baillie, P. W., Shaw, R. D., Liyanaarachchi, D. T. P. and Jayaratne, M. G. (2002). "A New Mesozoic Sedimentary Basin, Offshore Sri Lanka", EAGA 64th Conference \& Exhibition, Florence, Italy. 3-10.

3. Curray, J. R. (1984). "Sri Lanka: Is it a Mid-plate Platelet?", Journal of NARA, 31, 30-50.

4. Dissanayake, C. B. (2005). “A New Plate Boundary near Sri Lanka; Implications for Future Geo Hazards", Journal of the National Science Foundation of Sri Lanka, 33(1), 5-8.

5. Enomoto, Y. and Zheng, Z. (1998). "Possible Evidences of Earthquake Lightning Accompanying the 1995 Kobe Earthquake Inferred from the Nojima Fault Gouge", Geophysical Research Letters, 25(14), 2721-2724.

6. Eurocode 8 (EC8), (2005). EN1998 1: “Design Provisions for Earthquake Resistance of Structures, Part1: General Rules, Seismic Actions and Rules for Buildings", European Committee for Standardization, Brussels.

7. Fernando, M. J. and Kulasinghe, A. N. S. (1986). "Seismicity of Sri Lanka", Physics of the Earth and Planetary Interiors, 44: 99-106.

8. Guha, S. K. and Basu, P. C. (1993) "Catalogue of Earthquakes (M $\geq 3$. ) in Peninsular India", Tech. Document No. TD/CSE-1, Atomic Energy Regulatory Board, Mumbai, India, pp. 1- 70.

9. Gunasekara, K. W. (2000). "First Earthquake in Sri Lanka", Sunday Observer, p. 34.

10. Gutenberg, B. and Richter, C. F. (1954). Seismicity of the Earth and Associated Phenomena, $2^{\text {nd }}$ edition, Princeton: Princeton University Press.

11. Hughes, J. S. (1932-1967). International Seismological Summary, Oxford University Observatory, England.

12. Kularathna, E. K. C. W., Pitawala, H. M. T. G. A., Senaratne, A. and Weerasinghe, D. (2015). "Gondwana Breakup and Development of Sedimentary Basins in Sri Lanka". Proc. 31 st Annual Sessions of the Geol. Soc of Sri Lanka, pp.6.
13. Iyengar, R. N., Sharma, D. and Siddiqui, J. M.(1999). "Earthquake history of India in Medieval Times", Indian Journal of History of Science, 34(3), 181-237.

14. Menon, A., Ornthammarath, T., Corigliano, M. and Lai, C. G. (2010). "Probabilistic Seismic Hazard Macrozonation of Tamil Nadu in Southern India", Bulletin of Seismological Society of America, 1(3), 1320-1341.

15. Rana, M. S., Chakraborty, C., Sharma, R. and Giridhar, M. (2008). "Mannar VolcanicsImplications for Madagascar Breakup", 7th International Conference and Exposition on Petroleum Geophysics, 358- 364.

16. Rao, R. B. and Rao, S.P. (1984). "Historical Seismicity of Peninsular India", Bulletin of the Seismological Society of America,. 74(6), 2519 2533.

17. Rodriguez, J. (1616). "Relacion Verdadore del Esantoso Terremoto" (True Description of the Terrible Earthquake). 4-page pamphlet, Lisboa.

18. Sreejith, K., Krishna, K. and Bansal, A. (2008). "Structure and Isostatic Compensation of the Comorin Ridge, North Central Indian Ocean". International Journal of Geophysics, 175, 729-741.

19. Stepp, J. C. (1973). "Analysis of Completeness of the Earthquake Sample in the Puget Sound Area, in Seismic Zoning", edited by S.T. Harding, NOAA Tech. Report ERL 267-ESL30, Boulder, Colorado.

20. Thaldena, S., Perera, L. R. K. and Prame, W. (2013). "Present Status of Seismic Monitoring and Risk Assessment in and around Sri Lanka", Proceedings of the 4th International Conference on Structural Engineering and Construction Management. Kandy, Sri Lanka.

21. Uduweriya, S. B. (2014). Probabilistic Seismic Hazard Macrozonation In Sri Lanka. Master Thesis: University of Peradeniya.

22. Vitanage, P. W. (1995). "Seismicity in Lineaments -Impact on Engineering Structures", In Handbook on Geology and Mineral Resources of Sri Lanka. Second South Asia Geological Congress, GEOSAS - II,, pp 59 - 62. 